\title{
FELIPE BIGARNY A LA LUZ DE SU TESTAMENTO E INVENTARIOS DE BIENES
}

\author{
Luis VASALlo TORANZO ${ }^{1}$ \\ Universidad de Valladolid
}

\begin{abstract}
El hallazgo del testamento y de la totalidad de los inventarios, tasaciones — solo se conocía parcialmente la burgalesa-, almonedas y partija de los bienes de Felipe Bigarny permite desentrañar algunos de los interrogantes que rodeaban a su persona. En primer lugar se concreta parte de su periplo francés previo a su vecindad burgalesa, se prueba su relación con Gil de Siloe al llegar a Castilla, se aclaran algunas cuestiones familiares, se documentan ciertas obras inéditas y se repasan algunos de los artefactos de los que se rodeó y de los libros con los que se instruyó y sirvió para su práctica artística.
\end{abstract}

Palabras clave: Renacimiento; escultura; España; Felipe Bigarny; testamento.

\section{FELIPE BIGARNY IN THE LIGHT OF HIS WILL AND INVENTORIES OF ASSETS}

The discovery of the Will and all the inventories, valuations (only the one of Burgos was partially known), auctions and partitions of Felipe Bigarny's possessions allow us to unravel some of the questions surrounding his life. Firstly, it has been possible to specify part of his French tour prior to his residence in Burgos, and to demonstrate his relationship with Gil de Siloe upon arriving in Castile. Some family matters are clarified; certain unpublished works are documented; and a number of the devices he owned and the books he used to teach himself and formulate his artistic practice are listed in these archival papers.

Key words: Felipe Bigarny; Rennaisance sculpture; Spain; Will.

Cómo citar este artículo / Citation: Vasallo Toranzo, Luis (2019): "Felipe Bigarny a la luz de su testamento e inventarios de bienes". En: Archivo Español de Arte, vol. 92, núm. 366, Madrid, pp. 145-160. https://doi.org/10.3989/ aearte.2019.10.

El 11 de noviembre de 1542 el alcalde ordinario de Toledo acudió a un aposento del claustro alto de la catedral para levantar un cadáver. El cuerpo, que estaba amortajado y echado sobre un repostero, fue descubierto por el funcionario que dio fe del fallecimiento, al tiempo que ayudado por el escribano de la obra de la catedral y por tres criados del difunto - Francisco Manzano, el borgoñón Guillamón o Guillaume de Salinas y el entallador Gaspar de la Torre o Gaspar de Vitoria- reconoció al finado como Felipe Bigarny².

Maestre Felipe había muerto repentinamente esa noche en las dependencias que la fábrica catedralicia había puesto a su disposición en el claustro para que residiera y tallara las sillas del

\footnotetext{
1 vasallo@fyl.uva.es / ORCID iD: http://orcid.org/0000-0002-4720-2422.

2 Archivo de la Real Chancillería de Valladolid (ARCHV), Pl. Civiles, Zarandona y Walls (O), C. 606-8. Este trabajo se enmarca en el proyecto de investigación financiado por el Ministerio de Economía y Competitividad titulado La materialización del proyecto. Aportación al conocimiento del proceso constructivo desde las fuentes documentales (siglos XVI-XIX) (Ref. HAR2013-44403-9).
} 
coro $^{3}$. Allí le vio morir Gaspar de Vitoria, quien dio aviso a Gregorio Pardo, que a la mañana siguiente se lo notificó a la justicia para iniciar los trámites sucesorios. Entonces se abrió el testamento, que maestre Felipe había redactado en Burgos casi cuatro años atrás, concretamente el 8 de diciembre de 1538, con ocasión de una grave enfermedad ${ }^{4}$. El documento repite los formulismos al uso para la profesión de fe y los ritos funerarios a practicar, de manera que sorprende que ni siquiera buscase enterrarse con su primera mujer ni pretendiera una tumba en exclusiva para él, eligiendo para su descanso eterno la de su yerno Juan Glanet de Borgoña en San Ildefonso de Burgos. Ordenó ser enterrado con el hábito de San Francisco y encargó una misa diaria por su alma durante un año, en las que se entregarían como ofrendas un quintal de pan y un maravedí de vino, además de disponer que su viuda e hijos menores llevaran lutos durante ese tiempo. Todo lo referido a las exequias y al cabo de año lo dejó en manos de su viuda en función del dinero disponible.

Pero si las mandas relativas a su entierro y al bien de su alma pueden calificarse de rutinarias, las estipuladas para ordenar la herencia entre los hijos, parte de la cual estaba comprometida en obras inconclusas o impagadas, permiten profundizar sobre alguno de los interrogantes que siempre han acompañado a este maestro: formación y primeros años de profesión, encumbramiento social propio y de sus hijos, intervención en promociones arquitectónicas; o documentar alguna obra esquiva.

\section{Los primeros años}

Nacido, como es sabido, en el obispado de Langres, ducado de Borgoña ${ }^{5}$, hacia $1473^{6}$, su formación ha sido apuntada por Isabel del Río ${ }^{7}$, quien ha propuesto un aprendizaje en su patria antes de realizar un controvertido viaje romano, reconocido por él mismo al final de sus días ${ }^{8}$. El incierto desplazamiento a la capital de los Papas, contradicho por el estilo escultórico de sus primeras obras burgalesas - deudoras sobre todo de la plástica borgoñona ${ }^{9}$ - y confesado en el competitivo mercado toledano, en pugna con un Berruguete que se vanagloriaba de su formación italiana, es puesto en duda a partir de su testamento ${ }^{10}$. En él reconoce haber residido antes de llegar a Burgos en la ciudad de Uzès, en el Languedoc, donde se relacionó con el obispo Nicolás Maugras (1483-1505), en quien depositó "treçientos y çinquenta coronas de oro, que valen a tresçientos e çinquenta maravedís cada una, las quales yo tenía dadas en guarda al hobispo de Usés, mi señor, ques en Lenguador, las quales dichas treçientas coronas fuy a cobrar y las cobré dende a tres meses después de casados”. Esta pequeña fortuna en metálico -122.500 marave-

\footnotetext{
3 La fecha de la muerte de Bigarny, también en Del Río de la Hoz, 2000: 310. Felipe Bigarny había adquirido unas casas en el barrio del Cenizar de Toledo, donde residían su segunda mujer y los hijos habidos con ella.

${ }^{4}$ La testamentaría completa de maestre Felipe se halla en ARCHV, Pl. Civiles, Zarandona y Walls (O), C. 606-8. Se trata de una prueba documental aportada a un pleito de saneamiento por vicio oculto que movió en 1551 la Cartuja de Miraflores contra Clara Pardo, hija segunda de Bigarny, por la venta al monasterio de la casa y heredades que habían pertenecido al escultor en el barrio burgalés de Cortes. Parte de dicha documentación — un fragmento de la tasación de los bienes burgaleses y ciertos documentos de la partija - la publicó el Boletín de la Sociedad Española de Excursiones en 1914 a partir de una copia fragmentaria (40 folios de los 147 originales) hallada en dicho cenobio. Ahora se da a conocer la testamentaría completa, con numerosos documentos inéditos no incluidos en dicho artículo, entre ellos el testamento cerrado del artista, protocolizado el 8 de diciembre de 1538 ante el escribano burgalés Ortega de Revilla, y los inventarios y almonedas de Toledo y Burgos, así como ciertas informaciones soslayadas entonces. Las citas del testamento, inventarios y tasaciones no referenciadas en notas al pie proceden de este documento de la Chancillería de Valladolid.

5 Así lo declaró en 1498 cuando contrató los relieves del trasaltar de la catedral de Burgos. Martínez, 1866: 282.

${ }^{6}$ En 1513 confesó tener unos 40 años. ARCHV, Pl. Civiles, Masas, (F), C. 1028-9.

7 Del Río de la Hoz, 1984: 90-91.

8 Del Río de la Hoz, 2001: 19-22.

9 Redondo Cantera, 2015: 23-24.

${ }^{10}$ Agradezco a M. ${ }^{\mathrm{a}}$ J. Redondo sus comentarios sobre el discutible viaje romano de Bigarny, de los que estas líneas son deudoras.
} 
dís-, indicativa, bien de una desahogada posición familiar, bien de un notable éxito profesional en Francia, unida a su juventud (si admitimos que nació en 1473, tuvo que llegar a Burgos con unos 24 años) dejan poco espacio para la supuesta estancia en Roma. Esta, de haberse producido, hubo de ser efímera y en todo caso poco fructífera, pues de la escultura borgoñona deriva el canon corto aplicado a sus figuras y su capacidad para conjugar la idealización de algunas figuras religiosas, de serenas actitudes, gestos ausentes e innegable belleza formal, con el naturalismo basado en la individualización humana a través de estudios fisonómicos caracterizados por la variedad de gestos y adornos. También, la contundencia volumétrica, desplegada a partir de los amplios ropajes de blandos y complicados pliegues que envuelven a las figuras, o las composiciones colmadas de personajes, que se ordenan no en función de la perspectiva lineal, que necesariamente tuvo que conocer en su supuesto viaje italiano, sino de las tradicionales fajas superpuestas que saturan los planos, lo acercan a la escultura francesa y flamenca y lo alejan de la italiana ${ }^{11}$.

Seguramente fue el declive del ducado de Borgoña, asimilado por la corona francesa desde $1477^{12}$ y convertido en región fronteriza — primera línea de las disputas entre Francia y Maximiliano de Austria por el Franco Condado ${ }^{13}$ - lo que obligó a nuestro escultor y a otros muchos artistas a emigrar ${ }^{14}$. Lamentablemente, nada suyo se puede rastrear en Uzès ni en las promociones del obispo Maugras - que se hizo retratar en una medalla de bronce (uno de cuyos ejemplares conservó Bigarny hasta su muerte ${ }^{15}$ ) y favoreció a los cartujos de Valbona, donde edificó la capilla de Santa Filomena- ${ }^{16}$, pues el Languedoc perdió gran parte de su patrimonio durante las guerras de religión de la Edad Moderna.

El depósito del dinero en el obispo Maugras demuestra que Bigarny no consideraba su viaje a España como definitivo, por lo que adquiere verosimilitud su paso por Burgos durante su peregrinación a Santiago, tal y como él mismo insinuó en el contrato del primer relieve del trasaltar de la catedral ${ }^{17}$. Su inmediato éxito profesional debió de aconsejarle establecerse en la ciudad y tomar una esposa. La elegida fue María o Mari Saiz Pardo ${ }^{18}$, con la que tuvo que casar hacia 1502, pues en 1504 nació Clara Pardo, su segunda hija ${ }^{19}$.

No fueron solo esas 350 coronas francesas las aportadas por Bigarny a su primer matrimonio. Como arras entregó otros 20.000 maravedís, que se sumaron a los 80.000 con que fue dotada la prometida. Pero además Bigarny llevó al matrimonio abundantes bienes muebles de cierta riqueza, indicativos de una posición bien asentada en sus primeros años burgaleses:

E ansimismo tenía míos antes que me desposase unas oras que valían treynta ducados 20 ; e un anill con una turquesa grande, que vale vien treynta ducados; e un çabí [sic ¿por rubí?] que vale diez ducados; e un cuete [sic] de oro que valía ocho ducados; e una medalla que valía quatro ducados. E más tenía quatro tazas de plata que valdryan más de quarenta ducados; e más tenía muy buenos vestidos e aderezos de mi persona, ansí de seda como de paño e de chamelote, que podrían valer treynta ducados; e ansimismo un caballo que valdría beynte ducados, e más un macho de seys mill maravedís, el qual obe del padre de Diego de Silos [sic por Siloe]; e más un anillo de oro torçido que podría baler seys ducados; e un San Jorje de plata que valía quatro ducados; e una corneta que vale quatro ducados; e ansimismo cofres, e basijas, e menaje de casa...

11 Marías, 1989: 149-151.

12 Quarré, 1978: 25.

13 Baudoin, 1987: 15.

14 Camp, 1990: 170.

15 "Una medalla del hobispo de Usés, con su rreberso dorada". Inventario de los bienes de maestre Felipe en Toledo.

16 Charvet, 1870: 122-3.

17 Martínez y Sanz, 1866: 282.

18 Hija de Juan Pardo y Catalina Sanz de Salón. Carbonell Buades, 2017: 130, n. 23.

19 Del Río de la Hoz, 2001: 85 calcula su primer matrimonio entre 1502-5 en función de las edades de los primeros nietos de Bigarny; sin embargo, en un pleito de 1552, Clara Pardo confesó tener 48 años, aunque el escribano erróneamente copió 38. ARCHV, Pl. Civiles, Lapuerta (F), C. 762-1.

${ }^{20}$ Estas las tenía su hija Clara en 1538. 


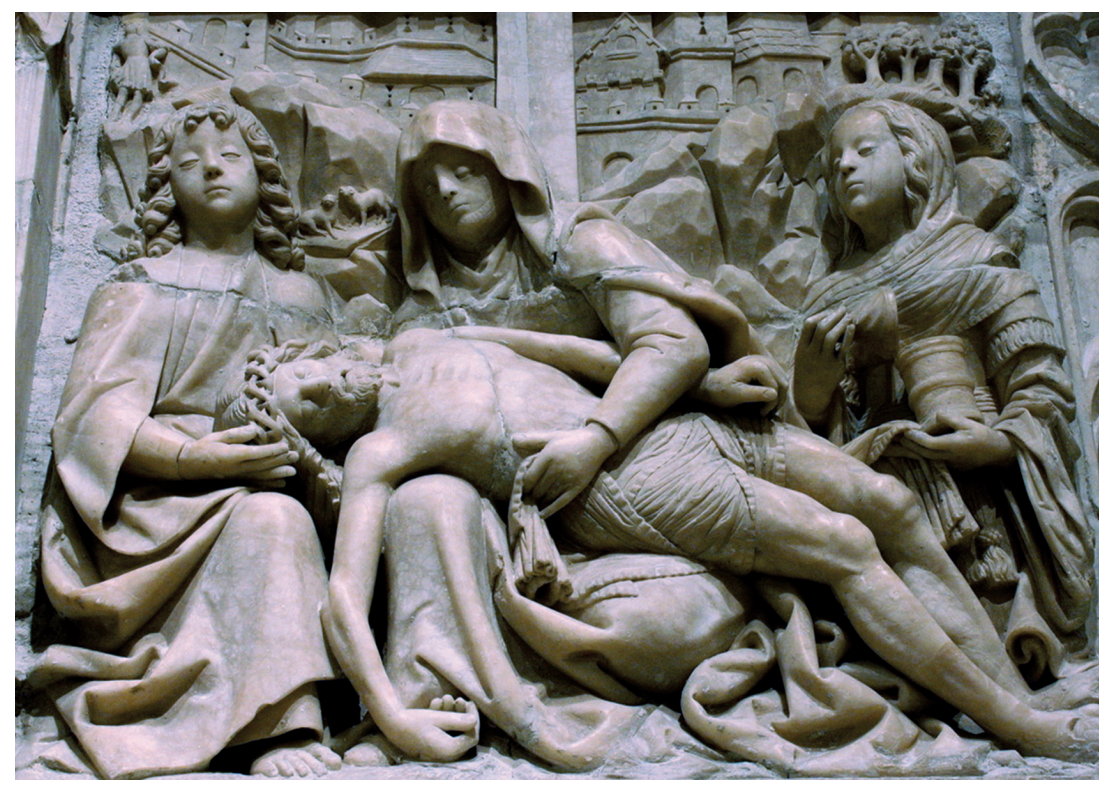

Fig. 1. Felipe Bigarny. Piedad. Sepulcro de Juan Padilla. Detalle. Museo de Burgos.

Esta desahogada situación de la pareja —más de 300.000 maravedís propios del borgoñón y 100.000 de la burgalesa, con las arras - es indicativa del fulgurante éxito profesional obtenido por Bigarny. Su carrera en el mercado escultórico burgalés tuvo que comenzar como oficial en los talleres de Gil de Siloe y Simón de Colonia, desde los cuales pasaría a relacionarse con algunos de los comitentes más poderosos: el cabildo, los condestables y ciertos mercaderes adinerados. La relación con Colonia y la catedral es conocida a través del contrato de 1498 para tallar el relieve del Camino del Calvario del trasaltar, que se completaría en años sucesivos con otros dos relieves más y las figuras sedentes de los apóstoles también para la girola. Los vínculos con el condestable tuvieron que comenzar muy pronto, pues fue el magnate quien lo casó con María Saiz Pardo ${ }^{21}$. El acercamiento a los adinerados mercaderes burgaleses se constata en el indocumentado retablo de la Adoración de los Reyes, encargo de Hernando de Castro en la parroquial de San Gil.

Por su parte, la conexión que lo unía a Gil de Siloe ha sido contemplada por todos los autores que han estudiado la escultura burgalesa de hacia 1500, algunos de los cuales han escudriñado sus últimas obras con la intención de descubrir su mano. Ahora que el propio Bigarny documenta su participación en el taller de Siloe, como se ha visto en el párrafo de su testamento transcrito arriba (a pesar de que el copista de 1551 equivocó Siloe por Silos, como por otra parte era habitual $)^{22}$, se puede buscar con mayor fundamento alguna de dichas aportaciones. No es este el lugar para embarcarse en el análisis de la producción tardía de Gil de Siloe, sin embargo un relieve del sepulcro de Juan de Padilla me parece evidentemente obra de Bigarny. Se trata de la Piedad ante la que reza eternamente el hijo del adelantado mayor de Castilla, muerto todavía doncel en la guerra de Granada (fig. 1). El relieve, que parece un añadido pues descompensa compositivamente el fondo del arcosolio - lo que provocó serias dudas sobre su ubicación cuando se montó el sepulcro en el Museo de Burgos-, se talló hacia 1500 dadas las similitudes formales - tratamiento de paños, tipologías de unos rostros idealizados, actitudes contenidas, paisaje urbano del segundo plano situado en una estrecha faja sobre rocas artificiosas... - con la Piedad del relieve del Descendimiento y Resurrección del trasaltar de la catedral ${ }^{23}$.

21 Del Río de la Hoz, 2001: 85.

${ }^{22}$ Es lo más probable, aunque hay que señalar que existió un mercader burgalés llamado Miguel de Silos, que tuvo un hijo, también mercader, llamado Diego de Silos, estante en Nápoles en 1524. ARCHV, Pl. Civiles, Taboada (O), C. 855-1.

${ }^{23} \mathrm{La}$ escena ha sido objeto de numerosos acercamientos debido a las diferencias estilísticas con el arte de Siloe, por lo que los estudiosos han basculado entre algún miembro de su taller y el de Bigarny. El propio Wethey (Wethey, 


\section{La promoción familiar: éxitos y contratiempos}

El triunfo profesional de maestre Felipe se trasladó a la situación familiar, para cuyos hijos procuró ventajosas carreras y matrimonios, sin que pudiera apartar de ellos algunos reveses y sinsabores, incluida la comisión de un homicidio.

Con su primera mujer tuvo al menos cinco hijos: Catalina, Clara, Gregorio, Josepe y Juan ${ }^{24}$. La primera casó - sin el permiso de maestre Felipe pero con la complicidad de la madre, que lo convenció para aportar 160.000 maravedís de dote, aplicados a los dineros que le debían por el retablo de Haro - con Hernando de Velasco o Hernando Ortiz de Velasco ${ }^{25}$. Muerto este, Catalina volvió a casarse. Lo hizo con un mercader enriquecido llamado Gonzalo Alonso de Burgos, que llevaba tiempo negociando con la familia del difunto Bigarny para desposarse con Clara, aunque la muerte de Hernando propició el matrimonio con la mayor de las Pardo, con quien no tuvo hijos ${ }^{26}$.

Clara Pardo casó con Juan Glanet de Borgoña, rey de armas de Carlos I, a cuyo poder llevó 1.000 ducados de dote ${ }^{27}$. Este cortesano de acomodada posición invirtió parte de su patrimonio en bienes raíces ${ }^{28}$ y se convirtió en prestamista y apoyo de los dos hijos de maestre Felipe que vistieron hábitos clericales ${ }^{29}$. De hecho, financió junto a Bigarny parte de los estudios y canonjías de Josepe y las prebendas que pretendió Juan, quien para alcanzarlas se embarcó en costosos pleitos y en un viaje a Roma ${ }^{30}$. Precisamente fue este último quien mató al rey de armas a causa de la devolución del préstamo que le había hecho sobre su herencia ${ }^{31}$. Condenado a morir ahorcado y al pago de una indemnización en favor de su hermana de 100 ducados anuales durante cuarenta años, fue perdonado a cambio de renunciar a su legítima en favor de Clara y de ingresar en religión, concretamente en la orden trinitaria.

Gregorio Pardo, como se sabe, casó en Toledo con una hija de Alonso de Covarrubias ${ }^{32}$. La relación de Bigarny y Covarrubias en Toledo fue bastante fluida. No sólo lo indica el matrimonio citado, sino también la deuda de 30 ducados que mantenía el arquitecto con el escultor, así como el hecho de que Covarrubias actuara como testigo de la tasación de parte de los bienes toledanos del difunto.

1936: 68-69) lo consideraba cercano a la escultura francesa del XV, lo que lo acercaría a Bigarny, como han recordado recientemente Payo y Matesanz (Payo/Matesanz, 2015: 173). Gómez Bárcena, por su parte, lo adjudicó a un discípulo de Siloe o a un miembro del taller de Bigarny, quien lo habría tallado sobre una composición del maestro flamenco (Gómez Bárcena, 1988: 163). Últimamente, Redondo ha propuesto a un joven Diego de Siloe, colaborador en el obrador de su padre (Redondo Cantera, 2017: 50). Sin embargo, el carácter idealizado e intimista de las figuras de este relieve no puede argumentarse para negar la autoría del joven Bigarny, pues la escultura borgoñona practicó dicha tendencia desde Claux de Werve, como se comprueba en la producción de Jean de la Huerta e incluso del tardío Antoine Le Moiturier (Boucherat, 2004 y 2012); además, los pesados paños que envuelven a San Juan y a la Virgen, recuerdan también los del trasaltar e incluso los de los bultos del sepulcro del doctor Pedro González de Santo Domingo en la catedral de La Calzada (Barrón García, 2009: 195 y ss.).

${ }^{24}$ Aunque este último aparece citado en algunos documentos como Joaquín o Julián, su verdadero nombre era Juan. La confusión era intencionada, causada por las dramáticas circunstancias en las que se vio envuelto y que se desvelarán a continuación.

${ }^{25}$ Oscuro personaje por quien maestre Felipe pagó 20 ducados a María de Cadiñanos, una criada de su cuñada Marta Pardo, a los que estaba obligado Velasco, seguramente por haberle prometido matrimonio.

${ }^{26}$ ARCHV, Pl. Civiles, Lapuerta (F), C. 762-1.

27 Maestre Felipe y Mari Saiz la pagaron con la venta de una casa burgalesa sita frente a la principal, de la que se obtuvieron 600 ducados del abad de Foncea, y de otra en Valladolid, con la que se completaron los 1.000 ducados.

28 ARCHV, Pl. Civiles, Lapuerta (O), C. 636-2 y ARCHV, Registro de Ejecutorias, C. 557-48, C. 712-38, C. $908-$ 22 y C. 1093-4.

${ }^{29}$ ARCHV, Pl. Civiles, Zarandona y Balboa (F), C. 668-5.

30 Todas las sinecuras pretendidas por ambos hermanos con las gestiones realizadas y cantidades invertidas por Bigarny quedaron reflejadas en el testamento.

31 El homicidio se produjo en 1538. Juan Glanet de Borgoña dejó dos hijos menores de 12 años: Juan Bautista y Marina.

32 Del Río de la Hoz, 2001: 350-1. Ahora, Carbonell Buades, 2017. 
La segunda mujer de Bigarny, Francisca de Velasco, hija de Catalina Temiño, mujer de Luis de Zuazo, llevó de dote al matrimonio 150.000 maravedís y recibió en arras varias joyas ${ }^{33}$. Con ella tuvo Bigarny al menos seis hijos (María Velasco, Felipa, Juan, Antonio, Francisco y Felipe), todos menores de doce años en $1543^{34}$. Tras vivir en Toledo después de la muerte del escultor, Francisca acabó asentada en Valladolid, donde testó en 1565. Para entonces solo vivían María, Juan y Antonio, a quienes nombró herederos, aunque mejoró a la primera porque la había sustentado en sus últimos años. Mandó enterrarse en el monasterio de San Pablo ${ }^{35}$.

\section{La proyección arquitectónica y su materialización}

La formación adquirida por Bigarny en la Francia bajomedieval sobre el tratamiento y la labra de la piedra estaba basada tanto en la geometría, fundamento de la proyección y de la práctica esterotómica capaz de materializar en el espacio la estructura trazada sobre el papel, como en su aderezo tallado ${ }^{36}$. Ello le permitió ejecutar no solo la labra decorativa y la escultura, por las que claramente se inclinó a lo largo de su carrera, sino cultivar también la proyección arquitectónica e incluso la práctica constructiva en función de sus cargos como veedor o perito, como ahora se verá.

Fue Isabel del Río quien a partir de las noticias que desde antiguo relacionaban al artista con determinadas obras de arquitectura riojanas y burgalesas atribuyó a Birgarny un importante papel en el diseño o ejecución de trabajos de arquitectura, que no habría que reducir solo a obras de marcado carácter ornamental (portadas de Haro y Casalarreina, o fachadas como la de la puerta de Santa María de Burgos) ${ }^{37}$, sino extenderla al planeamiento de edificios complejos (capilla de Gonzalo Díez de Lerma en la catedral burgalesa, el cimborrio catedralicio, la torre de Santa María del Campo y varias obras del entorno de los condes de Miranda) ${ }^{38}$.

La primera intervención documentada de Bigarny como tracista se fecha en 1508, cuando ayudó al marmolista toledano Francisco Guillén de Arellano, su habitual proveedor de jaspes, a dibujar una ventana que el toresano Juan Rodríguez de Fonseca, señor de las Tercias de Badajoz y miembro del Consejo Real, quería abrir sobre la portada de sus casas principales de la ciudad de Toro. El mismo Bigarny lo recordaba años después, cuando aclaraba que “...ayudó a traçar en un papel..." 39 el vano, claro precedente de los que años más tarde diseñaría para el palacio de Peñaranda de Duero, en los que repitió la misma articulación de antepecho sobre canes, pilastras, entablamento rematado por jarras laterales y escudo inscrito en una concha.

$\mathrm{Su}$ prestigio le permitió participar en los informes que se pidieron sobre las catedrales de Ávila y Salamanca ${ }^{40}$, e incluso la justicia lo nombró árbitro para dirimir desencuentros profesionales sobre obras de cantería. Es lo que ocurrió en 1515 cuando fue elegido para inspeccionar los supuestos errores constructivos cometidos por Francisco de Colonia en la cabecera de la iglesia de la Merced de Burgos. En el transcurso del pleito entre el cantero y los mercedarios, el

\footnotetext{
${ }^{33}$ Una cadena de oro con una cruz, tres sortijas, una con un diamante y otra con un rubí, y un topacio guarnecido de oro para la toca.

34 Sobre el número y los nombres de los hijos del segundo matrimonio de Bigarny, Fuentes, 2004: 9. Sobre el recorrido vital de estos, Del Río de la Hoz, 2001: 348 y ss.

35 Archivo Histórico Provincial de Valladolid (AHPV), Protocolo 282, 2-10-1565, ff. 222 y ss. No volvió a casarse, pues en el testamento se tituló "viuda de maestre Felipe". Respecto a María Velasco, viuda de Pedro de Langa, véase ARCHV, Pl. Civiles, Varela (F), C. 1234-2 y Del Río de la Hoz, 2001: 349-50.

36 Ibáñez Fernández, en prensa. Agradezco a Javier Ibáñez la consulta de este texto, donde desarrolla algunas ideas sobre las que venía trabajando desde tiempo atrás sobre la labor de Bigarny y otros escultores franceses como proyectistas de arquitectura en función de su formación en la tradición canteril de la Francia bajomedieval.

37 Del Río de la Hoz, 2000: 128 y ss, 267 y ss.

38 Del Río de la Hoz, 2000: 200-204, 267-281, 281-288, 327-333, 357-359.

39 Vasallo Toranzo, 2018b: 26-27.

40 Alonso Ruiz, 2003a: 64.
} 
alcalde de corregidor de Burgos llamó al borgoñón, "que es persona syn sospecha", para que actuase como tercero y aclarase los pareceres contrarios de los peritos nombrados por las partes ${ }^{41}$.

Pero su implicación en obras de arquitectura no se limitó a la actuación esporádica y circunstancial en obras de fuerte componente decorativo o como árbitro en enfrentamiento judiciales, sino que, tanto en la ciudad de Burgos, como en Peñaranda de Duero, parece haber jugado un papel protagonista como proyectista y veedor de obras, lo que justificaría su relación profesional con maestros de este oficio, incluso como formador de futuros arquitectos prestigiosos ${ }^{42}$. De hecho, los testamentarios de Íñigo López de Mendoza le daban un acostamiento anual de 20.000 maravedís "de la capilla del cardenal e obispo que fue de Burgos [...] que tiene en el monesterio de la Vid"43. El dato es relevante y complementa el aportado por Isabel del Río cuando Bigarny, estante ya en Toledo, apoderó a Juan Vizcaíno en 1539 para que se ocupara de la "obra de la Vid", lo que permitió a esta autora reconocer, en función de las similitudes entre la bóveda del cimborrio del monasterio y de la capilla de la Presentación de la catedral burgalesa, la participación de Bigarny en ambos edificios ${ }^{44}$. En realidad, la similitud es mucho mayor con la traza del cimborrio de la catedral guardada en el Archivo Histórico Nacional, la única conservada de una obra que concitó en 1540 a algunos de los principales maestros del reino: Siloe, Bigarny, Rodrigo Gil y Juan de Rasines. El dibujo, estudiado ahora por Ibáñez y Alonso, parece una primera aproximación a un proyecto mucho más complejo que la tradición historiográfica atribuye a Bigarny $^{45}$, pero permite vincular la bóveda de La Vid con la actividad proyectiva del francés, aunque fuera Pedro de Rasines quien la llevara a cabo una vez desaparecido maestre Felipe ${ }^{46}$. El acostamiento de los Zuñiga y Avellaneda no solo tenía que abarcar la obra arquitectónica, sino hubo de contemplar también la ejecución de los monumentos funerarios, que Bigarny no pudo tallar, a pesar de guardar en su casa toledana el modelo del rosto del prelado: "la medalla del cardenal de Burgos".

Junto a Vizcaíno, el más fiel colaborador de maestre Felipe en el foco de Peñaranda de Duero fue el cantero Pedro de Landa o de Holanda ${ }^{47}$, quien actuó como su aparejador en las obras de arquitectura que corrían por su cuenta. Así, el borgoñón ordenó a sus herederos acudir a Landa para conocer, por ejemplo, lo que se le debía por el retablo que el escultor había hecho años atrás en la parroquial de San Miguel de dicha localidad, máquina que había sido tasada en 132.000 maravedís, de los que se le adeudaban todavía unos 15.000. Igualmente, Landa conocía lo que se le debía a un oficial llamado Miguel de Olaeta y lo que se adeudaba a los que hacían los sepulcros del obispo de Tuy, "la quenta de todo lo qual tiene el dicho Pedro de Landa" 48 .

La labor de Bigarny como tracista y veedor de obras se afianza con algunas referencias insertas en sus inventarios de bienes. Sin poder calibrar la razón de que poseyera una "muestra del espital del cardenal don Pero González de Mendoça" (quizás por haber actuado en alguna deliberación sobre el edificio, en el que contrató el retablo y tuvo que pleitear con la institución por ello ${ }^{49}$ ), es evidente que el "libro de jometría" que poseía, que alcanzó la alta valoración de 6 reales en la almoneda toledana, era utilizado para su labor como tracista. Dicha actividad, prolongada a través de los años, es posible que la recogiera en un volumen que se reseñó como un "libro de muestras, cubierto en pergamino".

${ }^{41}$ ARCHV, Pl. Civiles, Varela (O), C. 122-4.

42 Alonso Ruiz, 2003a: 64.

${ }^{43}$ En diciembre de 1538, cuando Bigarny redactó el testamento, solo le habían dado 20 ducados de lo correspondiente a dicha anualidad, por lo que mandaba se cobrase el resto.

44 Del Río de la Hoz, 2001: 322 y 326

45 Ibáñez/Alonso, 2016: 176-194. Sobre el cimborrio de Burgos, también Payo/Matesanz, 2013: 45 y ss.

46 Contra este relato, Alonso Ruiz, 2003b: 51-52, defiende la intervención de Juan Gil en el cimborrio de La Vid.

47 Del Río de la Hoz, 2001: 334 y Alonso Ruiz, 2003a: 203 y 305.

48 Además del seguimiento de los sepulcros, Landa se comprometió a asentarlos a cambio de 200 ducados, de los que Bigarny le había abonado 66. Sobre lo oficiales que entallaron los arcosolios del obispo de Tuy, Marías, 1981: 428-429 y Del Río de la Hoz, 2001: 316-320.

49 Alonso Cortés, 1922: 132-135 y Del Río de la Hoz, 2001: 289 y ss. 


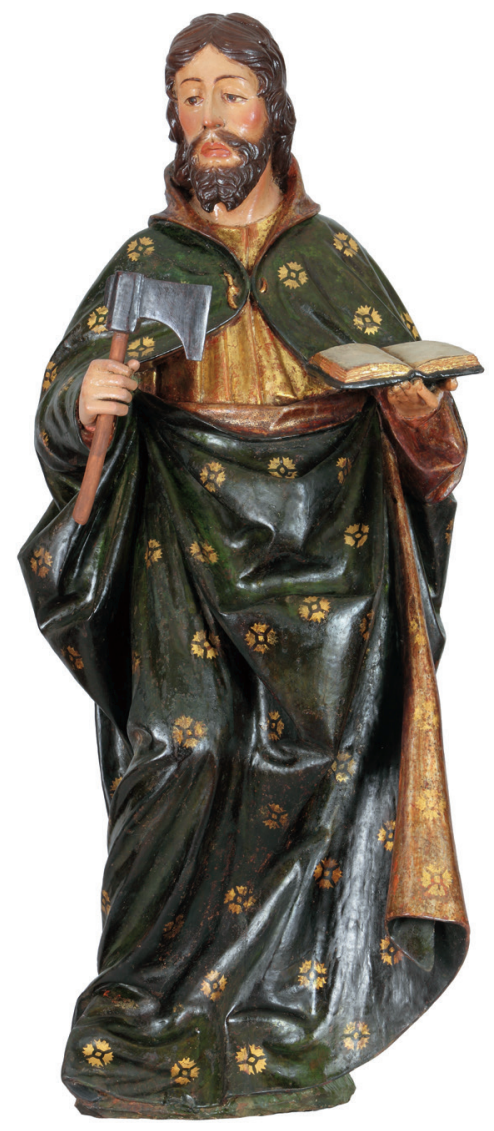

Fig. 2. Taller de Felipe Bigarny. San Judas Tadeo.

Retablo mayor de Ezcaray.

\section{Las obras de escultura: la foto fija de $\mathbf{1 5 3 8}$}

En el testamento, Bigarny recuerda con notable meticulosidad todas las obras pendientes de concluir o de cobrar. Muchas son conocidas, por lo que no voy entrar en ellas. Se trata de los desaparecidos retablos de Haro (La Rioja), San Miguel de Peñaranda de Duero (Burgos), Villamuriel de Cerrato (Palencia) ${ }^{50}$ y Bañares (La Rioja) ${ }^{51}$; y del existente de Valpuesta ${ }^{52}$, cuya mazonería corrió a cargo de Juan de Langres a cambio de 30.000 maravedís, aunque el oficial pedía 10.000 más. También citó los sepulcros pendientes. Es el caso de los bultos de los condestables para su capilla burgalesa $^{53}$, señores a los que estaba ligado mediante un acostamiento de 10.000 maravedís anuales, por lo que las imágenes se habían contratado de palabra y apelaba a la magnanimidad del noble para proceder a su cobro ${ }^{54}$; de los dos sepulcros parietales encargados por el obispo de Tuy para el monasterio jerónimo de Espeja - el del propio prelado, Diego de Avellaneda, y el de sus padres - de los que ya había cobrado 200.000 maravedís, una tercera parte del total ${ }^{55}$; y del sepulcro del obispo de Osma, Pedro González Manso, en San Salvador de Oña, todavía sin concluir su bulto de alabastro, concertado por 300 ducados, de los que le debían aún una tercera parte. Para el adorno de la cama de jaspe de esta sepultura había contratado, lo mismo que había hecho años atrás para la sepultura del obispo García de Loaysa en San Ginés de Talavera ${ }^{56}$, un escudo metálico con Pedro de Izaga, cerrajero y relojero burgalés, a cambio de 24 ducados $^{57}$.

Todavía Bigarny se refirió a cuatro retablos más en su testamento. El retablo mayor de Ezcaray estaba "sub judice" en 1538, por lo que encomendó a sus herederos "sacar la sentencia" - es decir, seguir el pleito y obtener la carta ejecutoria- y cobrar lo que se le adeudare. Barrón García lo ha puesto recientemente en relación con Bigarny, fechándolo entre 1515 y 1525 y haciéndolo derivar acertadamente del de los Reyes de San Gil de Burgos ${ }^{58}$. El retablo es uno de los trabajos de maestre Felipe que juega en contra de su posible viaje romano, pues la obra moderna se impone claramente sobre la renacentista — presente en la articulación del banco y las decoraciones superficiales de los doseletes-, aconsejando una fecha más temprana para su comienzo. Como ha señalado el propio Barrón García, esta gran máquina fue

${ }^{50}$ El retablo lo había dejado primero en manos de Guillaume de Salinas y después de Juan Vizcaíno. La policromía la había concertado con los burgaleses Lázaro de Azcoitia y Pedro de Vallejo a cambio de 40.000 maravedís. En 1538 había recibido 400 ducados por esta obra.

${ }^{51}$ Durante su estancia en Toledo, Bigarny lo traspasó a Juan Vizcaíno por 300 ducados, según una obligación que se anotó en el inventario de bienes de Toledo.

52 Cadiñanos Bardeci, 1979: 186; Del Río de la Hoz, 2001: 337-340 y Fuentes Rebollo, 2004.

53 Del Río de la Hoz, 2001: 211 y ss y Cadiñanos Bardeci, 1983: 346-348.

54 “....dello se a de cobrar lo que su señoría fuere serbido de mandar en gratificaçión de la dicha obra".

55 Sánchez Cantón, 1933. En el testamento recordó la obligación de abonar a Francisco Guillén de Arellano 200 ducados por los jaspes cuando se terminasen los cenotafios.

56 Se documenta así este sepulcro, atribuido a Bigarny por Nicolau Castro, 2003.

57 Sobre el arcosolio, sepulcro y escudos metálicos del obispo Manso, Loperráez Corvalán, 1788: 411; García Chico, 1941: 7-8; Cadiñanos Bardeci, 1987: 20-21 y Andrés Ordax, 2011: 29. Sobre este relojero y Bigarny, también Del Río de la Hoz, 2001: 203.

58 Barrón García, 2016: 356. 

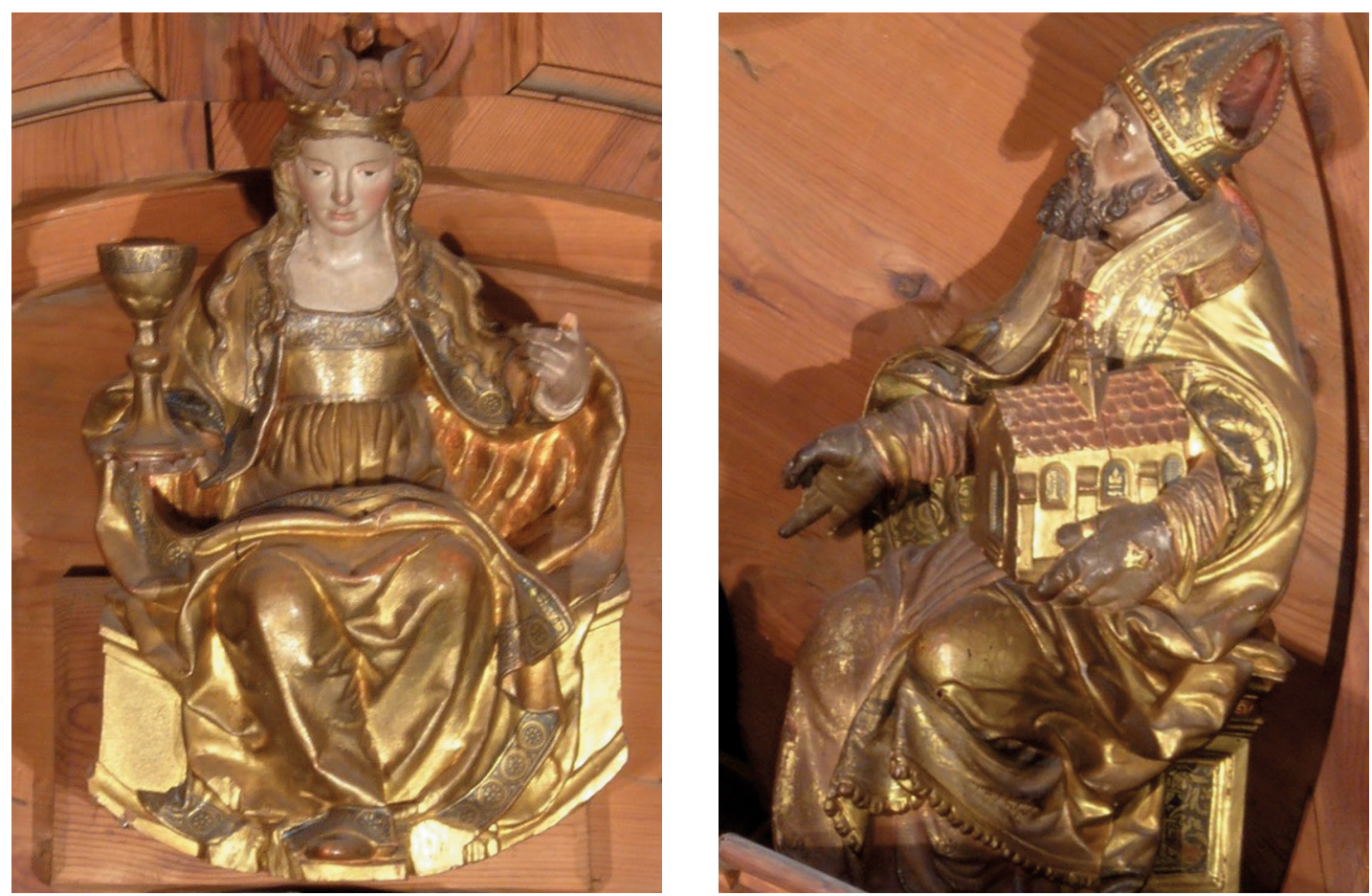

Figs. 3 y 4. Taller de Felipe Bigarny. La Fe y San Agustín. Retablo mayor del convento del Corpus Christi, Salamanca.

realizada por los oficiales burgaleses y norteños de Bigarny que trabajaban para él en Haro y Santo Domingo de la Calzada — se ha citado además a Hernando de Salcedo ${ }^{59}$-, quienes emplearon algunos de sus modelos, como se aprecia en las figuras de los apóstoles (fig. 2).

Para Cristóbal Suárez del Acebo, contador de Carlos I y regidor de Salamanca ${ }^{60}$, hizo el de la capilla mayor del convento del Corpus Christi de Salamanca, del que todavía le adeudaban 90 ducados en 1538. Cristóbal Suárez había fabricado el monasterio durante la década de 1530, pues en 1540 se aprobó en Roma el establecimiento del convento en los edificios construidos, entre ellos la iglesia ${ }^{61}$. Para vestirla se encargó a Bigarny el retablo mayor, lamentablemente desaparecido, pues fue renovado por dos veces en los siglos posteriores. Afortunadamente se han conservado tres imágenes originales: la Fe, San Agustín y San Ambrosio, colocadas bajo el cascarón del actual altar churrigueresco, realizadas en el taller de Bigarny, tal y como declara su estilo y policromía (figs. 3 y 4). No acabó aquí la responsabilidad de Bigarny respecto de este encargo. Como recordó a sus herederos, había prometido regalar al comitente "una imagen de Nuestra Señora de medio cuerpo arriba con un Jesús en los braços", seguramente uno de los medallones de madera o alabastro, de los que se han conservado algunos ejemplares, y de los que guardaba algunos más en su casa cuando murió.

Bigarny mencionó igualmente un pequeño retablo destinado a la capilla de San Ildefonso y Santa Catalina propiedad de Alonso de San Pedro y Catalina de Soria en Santa María la Redonda de Logroño ${ }^{62}$. La vieja capilla de los San Pedro-Soria desapareció con la iglesia, cuando se procedió a la reconstrucción del nuevo templo ${ }^{63}$. Realizado el reparto de los nuevos espacios

59 Del Río de la Hoz, 1986.

60 Carlos Morales, 2000: 401-402.

61 Portal Monge, 1984: 83-86 y Vasallo Toranzo 2018a: 17

62 Sobre este mercader y su mujer, miembro también de una conocida familia logroñesa de comerciantes, Goicolea Julián, 2007.

${ }^{63}$ Barrón García, 2015. 


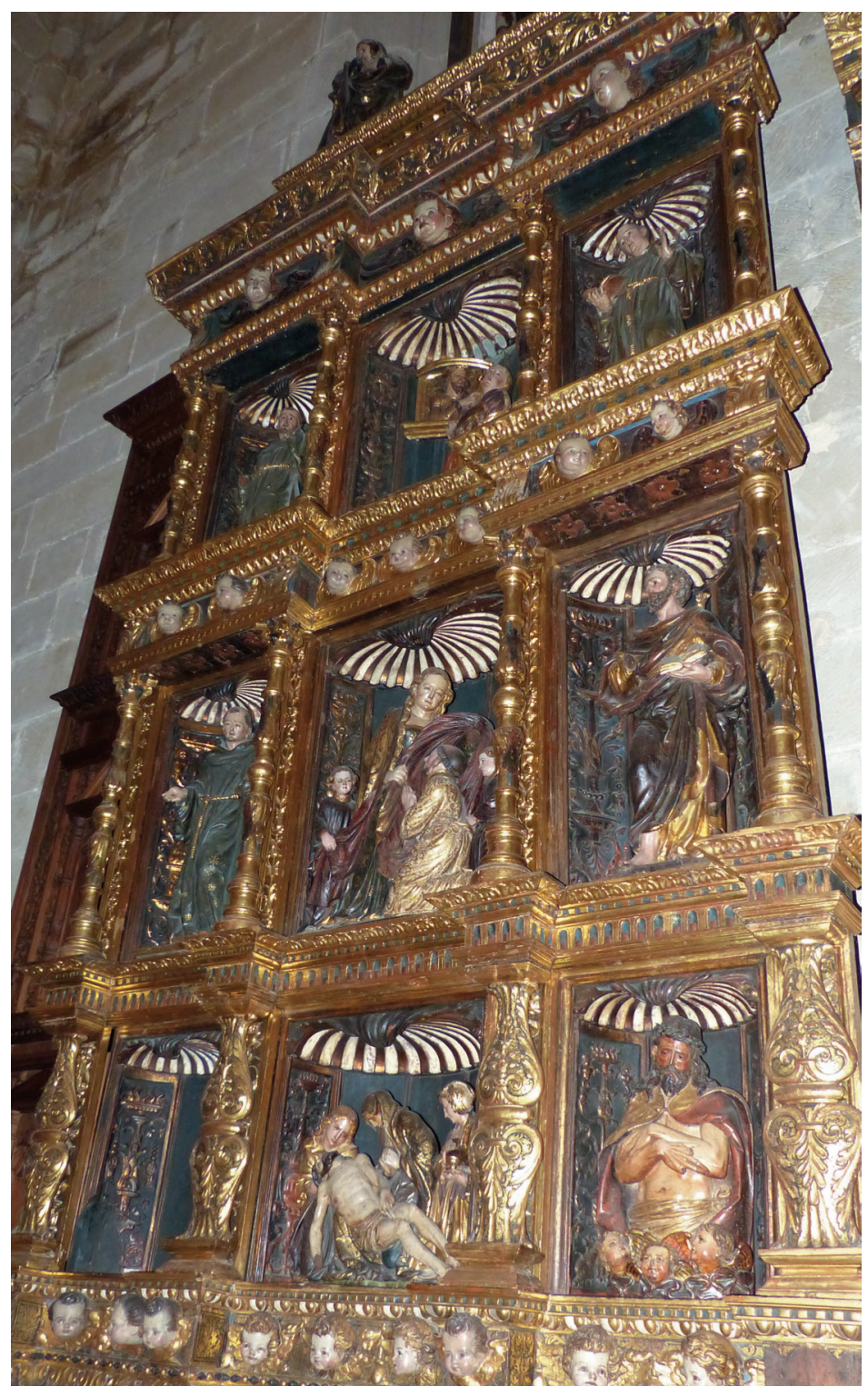

Fig. 5. Felipe Bigarny. Retablo de la capilla de San Ildefonso y Santa Catalina. La Redonda, Logroño.

privativos, al matrimonio se le adjudicó la capilla hornacina del tercer tramo del lado del evangelio, todavía en construcción en 1530 , cuando redactaron su testamento ${ }^{64}$. En dicho documento se ordenó a los cabezaleros concluirla y adornarla con un retablo y una reja. No hubo lugar para que actuasen los testamentarios. Catalina de Soria sobrevivió varios años a su marido, de manera que fue ella la que encargó el retablo a Bigarny a cambio de 120 ducados. En 1538 el escultor confesaba haber cobrado 70 y aclaraba que con el resto había que acudir a Cornielles imaginario, en realidad Cornielles de Amberes, que había realizado las esculturas a destajo, a razón de 4 reales el pie ${ }^{65}$. El moderado precio del retablo es indicativo de su tamaño: un pequeño mueble de tres calles de similar anchura — más salientes las laterales — articuladas mediante columnas

\footnotetext{
${ }^{64}$ ARCHV, Registro de Ejecutorias, C. 1730-14.

65 Una comparación de los destajos por la talla de imágenes en el mercado burgalés en el tercio central del XVI, Barrón García/Ruiz, 1993: 240, n. 12.
} 
abalaustradas, y dos cuerpos sobre una predela muy desarrollada; todo rematado con una cornisa muy volada que soporta un Calvario. Las imágenes, todas de bulto, se alojan en cajas rematadas con veneras, que cobijan esculturas individuales en las calles laterales (santos franciscanos y San Juan Bautista), y grupos en la central (Imposición de la casulla a San Ildefonso y Santa Catalina ante el emperador). En el banco se dispusieron algunas escenas de la Pasión: un Ecce Homo, una Piedad y otra figura desaparecida (figs. 5, 6 y 7) ${ }^{66}$.

Por último, el retablo mayor del convento de la Merced de Burgos precisa un análisis más detallado para aclarar la intervención de maestre Felipe ${ }^{67}$. El patronato de la capilla mayor había sido adquirido por el matrimonio formado por Francisco del Castillo y Leonor de Pesquera en marzo de 1514, aunque desde uno o dos años antes se habían responsabilizado de las obras de la iglesia $^{68}$. Esta había sido comenzada por Francisco de Colonia hacia 1511, posiblemente sobre una traza de su padre Simón, con la construcción de las capillas colaterales de la capilla mayor, contratadas por unos 80.000 maravedís ${ }^{69}$. Debido a los numerosos defectos apreciados, Colonia fue despedido y demandado por el convento en 1515, cuando ya la obra había pasado a ser controlada por Francisco del Castillo, que impuso a tres canteros vascos, los hermanos Pedro, Domingo (oficial de Colonia en la obra) y Martín de Villarreal, como maestros de la iglesia, que siguieron las trazas iniciales. Todavía en vida de Francisco del Castillo - murió en septiembre de 1519- se contrató el retablo con Felipe Bigarny, a quien se entregó cierto dinero ${ }^{70}$; si bien, la necesidad de esculpir y policromar las imágenes de la portada, de lo que se encargó también el borgoñón, le impidió comenzar el altar ${ }^{71}$; de manera que en 1528 Leonor de Pesquera reconocía que para fabricarlo sería necesario más dinero que el apalabrado años atrás ${ }^{72}$. El 21 de julio de 1536 se renovó el contrato, que alcanzó los 300.000 maravedís más 50 ducados, sobre la misma traza o "patrón" del primer intento, que contemplaba un retablo poligonal "de tres paños"73. La marcha de Bigarny a Toledo impidió su conclusión, de forma que a su muerte solo estaba hecha la predela con cuatro relieves (¿de los evangelistas?) ${ }^{74}$. Fallecidos los dos principales protagonistas del retablo (doña Leonor en 1541 y maestre Felipe al año siguiente) el monasterio puso pleito al nuevo patrono para que lo terminara ${ }^{75}$. Sentenciado a cumplir con el convento, Alonso del Castillo Pesquera demandó a los herederos de maestre Felipe, a quienes reclamó la conclusión de la obra o la devolución de los 62 ducados que según él había recibido Bigany. El escaso interés de Gregorio Pardo, desplazado a Toledo, le aconsejó desentenderse del proyecto y devolver el dinero cobrado por su padre, según dictaminó la Chancillería ${ }^{76}$. Desaparecida cualquier relación contractual con los herederos de Bigarny, se encargó una nueva traza al imaginero Juan de Villarreal, el discípulo de Siloe, quien acomodó su tamaño y calidad a los 300.000 maravedís previstos por la fundadora. En 1554 el patrono acordó con el monasterio concluir la máquina sin la policromía, que quedaba por cuenta del cenobio. Comenzó entonces la compra de

\footnotetext{
66 Moya/Ramírez/Ruiz-Navarro/Ruiz, 1975: 299.

67 Payo/Matesanz, 2015: 247-253.

${ }^{68}$ Los intentos para atraerse benefactores resultaron ineficaces hasta la participación del matrimonio CastilloPesquera. Incluso se recurrió al Rey Católico, invitado a visitar el convento y al que se solicitó una limosna que nunca entregó. ARCHV, Pl. Civiles, Moreno, (F), C. 732-3.

${ }^{69}$ ARCHV, Pl. Civiles, Varela (O), C. 122-4.

70 "Entre tanto que se haze el rretablo", el matrimonio entregó "una manta de deboçión rrica de tapicería de los Tres Reys", que se cubriría con un palio con su cielo y sus paramentos de antepuertas de seda de figuras. En 1546 el tiempo había hecho estragos sobre los tejidos, y un testigo comentaba que "el rretablo que al presente está puesto [...] es muy biejo e yndeçente, y está cubierto lo más dél con tapizes biejos e con una carta de lienzo pintada". ARCHV, Pl. Civiles, Moreno, (F), C. 732-3, testimonio de Gómez de Quintanadueñas.

71 ARCHV, Pl. Civiles, Moreno, (F), C. 732-3, juramento de calumnia de Alonso del Castillo Pesquera en 1546.

72 ARCHV, Pl. Civiles, Moreno (F), C. 732-3, codicilo de Leonor de Pesquera, en Burgos a 5-2-1528.

${ }^{73}$ El contrato, en ARCHV, Pl. Civiles, Masas (F), C. 810-1. En el testamento, Bigarny redondeó la cantidad estipulada hasta los 350.000 maravedís, de los que confesó haber recibido 60 ducados.

74 En el inventario de Burgos se anotaron "quatro piezas del vanco de Nuestra Señora de la Merzed con todo su aderezo",

75 ARCHV, P1. Civiles, Moreno, (F), C. 732-3.

76 ARCHV, Registro de Ejecutorias, C. 713-24.
} 

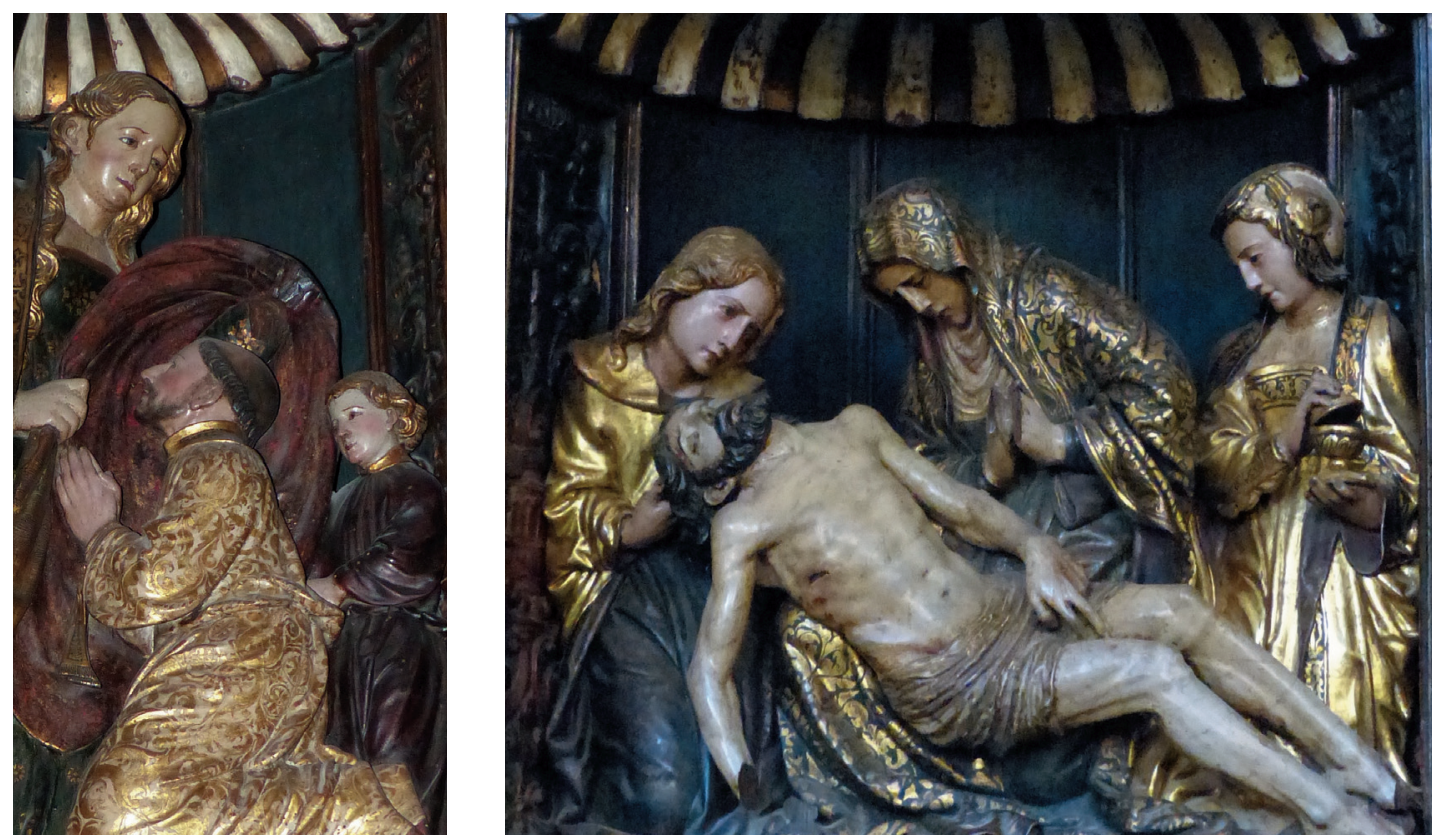

Figs. 6 y 7. Taller de Felipe Bigarny (Cornielles de Amberes). Imposición de la Casulla a San Ildefonso y La Piedad. Retablo de la capilla de San Ildefonso y Santa Catalina. La Redonda. Logroño.

madera y la contratación de los artistas, en particular del escultor "Adrián imaginario", seguramente Adrián de Bedoya, a quien Castillo pagaba un destajo de 12 ducados mensuales y al que habría que atribuir los seis tableros conservados en el Museo de Burgos ${ }^{77}$.

\section{Inventarios y almonedas}

Se hicieron tres inventarios, dos en Toledo - en el taller de la catedral y en sus casas del barrio del Cenizar-, y otro en Burgos, en sus casas en el barrio de San Juan, junto al río de la Moneda, cuyas traseras se abrían a la plaza de San Ildefonso. En ellos se distinguieron, por un lado, los bienes de los talleres, donde se contaron numerosas herramientas, dibujos y modelos, así como imágenes y relieves concluidos o no; y, por otro, el utillaje de las diferentes casas, tanto el mobiliario como las colgaduras y tejidos ornamentales, el menaje de la cocina y las joyas, la plata y los libros acumulados a lo largo de su vida.

Aunque lejos de la opulencia y variedad de los inventarios de los señores, Bigarny contaba con todo lo necesario para desarrollar su labor profesional dentro de un ambiente relativamente confortable. Incluso en la cámara que usaba en el claustro de la catedral de Toledo - pequeño espacio donde es posible aquilatar los artefactos de los que se rodeó- contaba con los muebles y adornos convenientes para un personaje de su categoría. El suelo se protegía con una alfombra mediana, valorada en dos ducados. Las paredes estaban engalanadas con colgaduras de diversa naturaleza. Concretamente con dos reposteros, uno con un "escudo de un león", viejo, tasado en dos ducados y adquirido por el rejero Domingo de Céspedes, y otro aún más antiguo, con una "rueda de rrétulos", valorado en ducado y medio, que se llevó Juan Correa de Vivar; con dos tapices de figuras viejos, y con dos antepuertas, una de "boscaje y otra de verdura, traydas".

${ }^{77}$ Los entalladores fueron Simón Francés y Juan de Malavellosa, que realizaron la mazonería con madera de Barbadillo del Pez. ARCHV, Pl. Civiles, Alonso Rodríguez (F), C. 137-1, $7^{\mathrm{a}}$ pieza y Moreno (F), C. 732-3. Sobre estos relives, Estella Marcos, 1979: 67-73 y Barrón/Ruiz, 1993: 246-248 y 253-254. 
Igualmente, se contaban los muebles necesarios: una cama "de nogal torneada, muy buena, con sus guarniçiones e manzanas doradas", donde dormía el artista, y otras de cordeles para sus criados; una mesa "ochabada, de nogal, e un pie de pino"; cuatro "sillas de espaldar de cuero", siete almohadas de estrado y varios muebles para almacenar objetos, como un "armario grande, de pino, nuebo" y distintas arcas y cofres donde había recogido algunos libros, medallas, escrituras, además de varios objetos de oro, plata y piedras preciosas.

El número de libros era relativamente abundante. En Burgos había dejado catorce con guardas de tablas, en latín y francés, y otros diecisiete encuadernados en pergamino, de los que lamentablemente no se reflejó el título o la temática, salvo un "Flos Sanctorum en romance". En Toledo, además de los libros de muestras y figuras que empleaba para componer las imágenes talladas, tenía a su disposición más de una docena de libros de variada temática. Los más abundantes eran los religiosos, entre los que se contaban dos horas, unas de "luminaçión, de pargamino, viejas", y otras "grandes, de Çaragoza", valoradas en unos escasos 2 reales cada una, porque a las últimas se les había quitado la guarnición de plata; una Generación de Adán, con tapas de hojalata; un "misal romano en quarto", tasado en 6 reales; un Breviario romano con su guarnición de plata, en 9 reales; "dos figuras de la Vribia, unas en latín e otras en franzés", valoradas en 3 reales; una "Natura angelical"; un "Tránsyto de la muerte" para bien morir, en 40 maravedís; y por último, un "Misterios de la misa" y un "Flor de Virtudes" encuadernados juntos en un solo volumen, a 2 reales. Poseía también dos libros de historia: una Crónica de Francia en dos volúmenes, tasado en 6 reales, y un "libro grande de la Fundaçión de Roma" (¿el Ab urbe condita de Tito Livio, traducido al francés en el S. XIV?). Los dos volúmenes más caros eran un "libro Hervolario", valorado en 6 ducados, y, sobre todo, un manuscrito sobre alquimia, tasado en 20.

La publicación de la tasación de los bienes burgaleses me dispensa de su análisis, realizado ya por Isabel del Río ${ }^{78}$. Solo quiero indicar que entre lo no publicado en 1914 predominaban los objetos del mobiliario de la casa, algunas armas y unos pocos elementos propios de la profesión de escultor: varias piezas de alabastro y "unos moldes de yerro de vaçiar medallas, son tres piezas". Además, es necesario contrastar la transcripción de la tasación de los bienes burgaleses realizada por los monjes cartujos y publicada por el Boletín de la Sociedad Española de Excursiones en 1914 con la del documento de la Chancillería. Por ejemplo, las " 100 piedras de tabernáculo", que se interpretaron como aras preparadas para su venta, eran en realidad "çien pilares de tabernáculo"79. Igualmente, respecto de los útiles considerados mecanismos para proceder al traslado de puntos, no pueden admitirse como tales el "garavato", pues no era más que un hierro con un gancho, ni la "caja con moldura de nogal redonda para una imagen", en realidad un marco para contener seguramente un relieve, que podía ser de madera o de alabastro, como se cita inmediatamente después. También es muy problemático identificar con un "definidor" albertiano, un artilugio inventariado en Burgos como un "pedaço de tablón de nogal y una pesa de piedra con su argolla detrás de la puerta" ${ }^{\circ 0}$, reseñado junto a un número muy limitado de moldes de yeso - solo dieciocho- - Y tampoco necesariamente tienen que corresponder a variados sistemas de traslados de puntos — cuyo uso no confirma la variedad estilística de las imágenes salidas del taller del maestre - otros objetos existentes en Toledo, como una "caja con su manequín", que se tasó en la abultada cifra de dos ducados, o un "maniquini de metal desquilado", piezas que posiblemente fueran utilizadas para componer modelos sobre los que rebotar - seguramente a partir de la talla directa- las imágenes en el taller ${ }^{81}$.

En Toledo se hicieron dos inventarios y una almoneda, donde participaron algunos artistas relacionados con el maestro. En ellos, además de los muebles y el menaje de la casa, descrito más arriba, se recogieron también las joyas y la plata. Entre las primeras se contaron las siguientes

78 Del Río de la Hoz, 2001: 344-348.

79 Del Río de la Hoz, 2001: 344.

${ }^{80}$ Los transcriptores cartujos leyeron "detrás della puesta". VV. AA. (Padres cartujos de Miraflores), 1914: 266 y Del Río de la Hoz, 2001: 346-347.

${ }^{81}$ Sobre la observación de la naturaleza y el desarrollo de la antropometría por parte de Alberti y Leonardo, todavía Panosfky, 1970: 83 y ss. y p. 95, n. 26. 
piedras: un diamante, una turquesa, un rubí, un jaspe verde, dos "piedras lápide" y dos cornalinas, una de color azul y otra de color ojo de gato, todas ellas engastadas en sendos anillos, las mejores de las cuales se tasaron por los plateros Hernando de Castrión y Melchor de Santa Cruz, vecinos de Toledo, en 20 ducados. Entre la plata se inventarió un jarro flamenco, un salero apedreado y labrado, dos tazones, uno dorado y otro blanco, un salero pequeño dorado, un tazón grande, empeñado por tres ducados en manos de su criado Guillaume de Salinas, una copa con su sobrecopa y una salvadera. Entre las piezas de oro destacaban un camafeo guarnecido de oro, una cadena de oro francés, unas arracadas y varios adornos de ropas en forma de pinjantes y botones.

A medio camino entre las joyas y los objetos conmemorativos se encontraban las medallas y momos. Aficionado a su posesión desde su juventud, cuando obtuvo una de su protector el obispo de Uzès ${ }^{82}$, acumulaba numerosas de plata, cobre, plomo y estaño metidas en cajas ("otra caxa con unas medallas de plomo e de metal", "una caxica que tiene diez e ocho medallas de plata", "otra caxica con tres medallas de plata e una de cobre"). Las de plata eran poco abundantes, como la del Emperador ${ }^{83}$, u otra pequeña que no se identificó. Las de plomo y estaño sumaban un total de cuarenta y cinco y se tasaron a cuarto de real cada una cuando se vendieron a varios vecinos toledanos, entre ellos, el entallador Francisco Manzano, que compró trece, y el platero Duarte Rodríguez, que llevó siete. Junto a ellas, conservaba algunas más grandes, realizadas por él en yeso, metal o alabastro, varias de ellas modelos de monumentos funerarios. Es el caso del rostro del cardenal Íñigo López de Mendoza, ya comentada; y quizás tuvieran la misma finalidad "otra medalla del condestable", "otra començada del Cardenal", sin especificar a quién se refería, y otra "de una monja". Igualmente poseía algunas de Cristo ("una medalla de Cristo, de metal", "una medalla con un rrostro de Cristo con su moldura de nogal, de alabastro", "otro rostro de Cristo de alabastro", "otras dos medallas de rostro de Ihesu Christo con un serafín debaxo e una palomita en una urna, destaño e otra de piedra") y de alguna figura representativa de la política contemporánea, como la del "cardenal don fray Francisco Ximénez", la única conservada; o la de una "reyna de Françia". Gregorio Pardo se quedó con siete "medallas de rretratos" y dos de "rrostros de Cristo", así como con cuatro pequeñas de figuras y nueve de metal. En Burgos, maestre Felipe había dejado trece de plomo, sesenta y seis de "tierra" y otras cuatro sin especificar ni su material ni su iconografía. Para la realización de las medallas de alabastro, poseía en Toledo varias placas rectangulares, ovaladas y circulares destinadas a la elaboración de retratos de distintos comitentes, relieves de la Virgen con el Niño y rostros de Cristo.

Las imágenes terminadas o a medio concluir que quedaron en Toledo no fueron tan numerosas como las que se inventariaron en Burgos, dado que las preparadas para la sillería no se reseñaron. Se contaron dos "ymáxenes de Sant Antonio de alabastro, una acabada y polida e la otra desbastada", que se tasaron en dos ducados; "quatro historias de peral, rebotadas", "una ymajen de pino de hasta medio cuerpo", "una cabeza de niño, de bronze", que se la reservó Gregorio Pardo; una escultura de madera de Santiago, que se tasó en 8 reales, "una poma de madera de boxo con dos ystorias" y dos relieves pequeños de la Pasión, uno de la Quinta Angustia y otro de la Flagelación.

Más interesantes eran los libros de modelos y estampas que utilizaba en su labor diaria. Para componer los relieves de la sillería toledana se valía, entre otros, de un "libraco de las figuras de la bribia ystoriado". Los dibujos propios o ajenos los había agrupado en distintos códices: "un libro de debuxos de mano", que se tasó en 2 reales, y "un libro de debuxos de la gran marca, sin guarniçión, con otros papeles de molde y mano", que se valoró en la crecida suma de 2,5 ducados. También tenía pliegos sueltos, como las "seys hojas de devuxo de molde de marca mayor con otros papelicos questán dentro, seys rreales"; "más veynte papeles de devujos" o los "tres pliegos de papel con seys figuras" tasados a real la hoja; o el papel con una figura de Flandes dibujada. Conservaba varios modelos o trazas dibujadas, como un "modello de la sepoltura del cardenal (sic) Fonseca", seguramente del patriarca de Alejandría, que finalmente haría Diego de Siloe. En la almoneda, distintos maestros pujaron por alguno de estos libros y papeles. El escultor Nicolás de Vergara el Viejo llevó varios papeles de dibujos por 9,5 reales en total. Igualmente, en Gaspar de Vitoria se remató un libro

\footnotetext{
82 Ver nota 14.

83 Sobre las medallas de Carlos V en la década de 1530, Campos Sánchez-Bordona, 2013: 386.
} 
de figuras en un real; y en manos de Gregorio Pardo quedó el libro de figuras de la Biblia y tres pliegos de papel "donde ay quatro ebangelistas e unas mugeres e una danza".

\section{Conclusiones}

La mentalidad práctica y tremendamente previsora que demuestra Bigarny en su testamento, preocupada por no dejar nada la albur de las circunstancias, resulta una oportunidad para el investigador, siempre quejoso del laconismo documental. Esta característica de su personalidad le llevó a elaborar un "libryto de memoria con guarniçión de plata", donde con toda seguridad reseñaba circunstancias y acontecimientos profesionales, personales y familiares, y del que tuvo que servirse para componer sus últimas voluntades. Obligado por la existencia de herederos nacidos de dos esposas distintas, el artista detalló con minuciosidad lo aportado a cada matrimonio, los gananciales producidos en cada uno y lo invertido en los hijos mayores. Todo ello permite no solo conocer o documentar alguna obra esquiva, sino aclarar ciertas circunstancias que caracterizan su labor profesional. En este sentido, se pone en duda su viaje romano, confesado por él mismo al final de sus días, que, en todo caso, de haberse producido, resulta prácticamente irrelevante a tenor de su práctica escultórica y arquitectónica inicial. Se incide en su papel como tracista y veedor de obras de arquitectura, en relación con lo cual se da a conocer el acostamiento que gozaba como maestro de la capilla de La Vid. Un acostamiento similar lo unía a los condestables, para quienes realizaba las labores escultóricas necesarias. En los variados documentos que componen la testamentaría aquí estudiada, se desgranan los oficiales de los que se servía en Burgos, Peñaranda de Duero y Toledo, así como los maestros con los que se relacionaba, sobre todo en la última ciudad, algunos de los cuales adquirieron varios de sus bienes. Los libros de los que se rodeaba permiten acercarnos a sus inquietudes y conocer los modelos de los que se servía para su práctica profesional. Por último, la lectura correcta de los inventarios me ha permitido desechar la utilización en su taller de variados mecanismos de traslado de puntos en época tan temprana, circunstancia que, además, de haberse producido, no encontraría fácil acomodo en relación a la variedad de estilos y manos que se aprecian en sus retablos y sepulcros.

En definitiva, este artículo pretende ser un primer acercamiento a una documentación que por su riqueza y variedad faculta para profundizar en una de las figuras señeras de nuestro siglo XVI.

\section{BIBLIOGRAFÍA}

Alonso Cortes, Narciso (1922): Datos para la biografia artística de los siglos XVI y XVII, Madrid.

Alonso Ruiz, Begoña (2003a): Arquitectura tardogótica en Castilla. Los Rasines, Santander, Universidad de Cantabria.

Alonso Ruiz, Begoña (2003b): "De la capilla gótica a la renacentista: Juan Gil de Hontañón y Diego de Siloé en La Vid". En: Anuario del Departamento de Historia y Teoría del Arte, XV, 2003, pp. 45-57.

Andrés Ordax, Salvador (2011): "Negligencia del colegial, catedrático, presidente de la Chancillería y obispo Pedro González Manso († 1539)". En: Boletín de la Real Academia de Bellas Artes de la Purísima Concepción, 46, pp. 19-32.

Barrón García, Aurelio (2009): "Espacios funerarios renacentistas en la catedral Calceatense". En: Azofra, Eduardo (ed.), La catedral Calceatense desde el Renacimiento hasta el presente, Salamanca: Gobierno de la Rioja, pp. 149-200.

Barrón García, Aurelio (2015): "Martín Ruiz de Álbiz y San Juan de Arteaga, arquitectos de la catedral de Santa María la Redonda en Logroño (1523-1529)”. En: Goya, 353, pp. 263-287.

Barrón García, Aurelio (2016): "La obra de Felipe Bigarny en Haro: a propósito de dos imágenes inéditas del retablo de Santo Tomás de Haro (La Rioja)”. En: Artigrama, 31, 2016.

Barrón, Aurelio / Ruiz, María P. (1993): “Diego Guillén, imaginario burgalés (1540-1565)”. En: Artigrama, 10, pp. 235-272.

Baudoin, Jacques (1987): La sculptur flamboyante en Bourgogne et Franche-Comté, Sigmaringen: Edt. Créer.

Boucherat, Veronique (2004): "Nouveaux éclairages sur l'oeuvre de Claus de Werve". En: Fliegel, S. y Jugie S. (eds.), L'art à la cour de Bourgogne. Le mécénat de Philippe le Hardi et de Jean sans Peur (1364-1419), Les princes des fleurs de lis. Catalogue de l'exposition, París, pp. 317-328.

Boucherat, Veronique (2012): "Jean de la Huerta et Antoine le Moiturier, imaginers de Philippe le bon: l'exemplarité d'un dossier opaque". En: Annales d'histoire de l'art et d'archeologie, 34, pp. 7-30.

Cadiñanos Bardeci, Inocencio (1979): "La iglesia de Valpuesta y su retablo, obra del escultor Felipe Bigarny". En: AEA, LII, 206, pp. 186-194. 
Cadiñanos Bardeci, Inocencio (1987): "Dos sepulcros y un retablo renacentistas en Oña y Quintanaopio (Burgos)”. En: Goya, 199-200, pp. 20-26.

Cadiñanos Bardeci, Inocencio, (1983): "Felipe Bigarny, Alonso Berruguete y los sepulcros de los Condestables en Burgos”. En: AEA, LVI, 224, pp. 341-354.

Camp, Pierre (1990): Les imageurs bourguignons de la fin du Moyen Âge. En: Les cahiers du Vieux-Dijon, 17/18. Dijon.

Campos Sánchez-Bordona, María D. (2013): “Melior Traiano, Felicitor Augusto. Medallas y medallones al servicio de la propaganda e imagen imperial de Carlos V". En: Castro, Ana / García, Joaquín (coords.), La impronta humanistica (ss. XV-XVIII). Saberes, visiones e interpretaciones, Palermo: Officina di Studi Medievali, pp. 377-392.

Carbonell Buades, Marià (2017): "Gregorio Pardo, Burgensi sculptori clarissimo: Una hipótesis italiana para el hijo de Maestre Felipe”. En: Gaeta, Letizia (dir.), Napoli e la Spagna nel cinquecento. Le opere, gil artisti, la storiografia, Salento: Mario Congedo Editore, pp. 127-150.

Carlos Morales, Carlos J. de (2000): “Cristóbal Suárez”. En: Martínez, José (dir.), La Corte de Carlos V, Segunda Parte. Los Consejos y los Consejeros de Carlos V, III, Madrid: Sociedad Estatal para la Conmemoración de los Centenarios de Felipe II y Carlos V, pp. 401-402.

Charvet, Georges (1870): La première Maison d'Uzès. Étude historique et généalogique sur la première Maison d'Uzès, Alès, Typographie J. Martin. https://books.google.es/books?id=kFoRAQAAIAAJ\&printsec=frontcover\&hl=es\&sourc $\mathrm{e}=$ gbs_ge_summary_r\&cad $=0 \# \mathrm{v}=$ onepage $\& \mathrm{q}=$ Maugras $\& \mathrm{f}=$ false [Consultado el 15 de febrero de 2018].

Del Río de la Hoz, Isabel (1984): "Felipe Bigarny: origen y formación”. En: AEA, LVII, 225, pp. 89-91.

Del Río de la Hoz, Isabel (1986): "Hernando de Salcedo y los retablos de Valgañón y Ezcaray”. En: Segundo Coloquio sobre Historia de La Rioja, 3, Logroño, pp. 125-142.

Del Río de la Hoz, Isabel (2001): El escultor Felipe Bigarny (h. 1470-1542), Salamanca, Junta de Castilla y León.

Estella Marcos, Margarita (1979): "Obras escultóricas del siglo XVI en los conventos de la Trinidad y de la Merced en Burgos". En: $A E A, 52,205$, pp. 55-73.

Fuentes Rebollo, Isabel (2004): "Vigarny, Picardo y el retablo de la colegiata de Valpuesta (Burgos)". En: Boletín del Museo Nacional de Escultura, 8, pp. 7-13.

García Chico, Esteban (1941): Documentos para el estudio del Arte en Castilla. T.II. Escultores, Valladolid: Universidad de Valladolid.

Goicolea Julián, Francisco J. (2007): "Mercaderes y hombres de negocio: el poder del dinero en el mundo urbano riojano de fines de la Edad Media e inicios de la Edad Moderna”. En: Hispania. Revista Española de Historia, 67, 227, pp. 947-992.

Gómez Bárcena, María J. (1988): Escultura gótica funeraria en Burgos, Madrid: Diputación de Burgos.

Ibáñez Fernández, Javier (en prensa): "Los franceses y lo francés en la arquitectura de la Península Ibérica durante los siglos

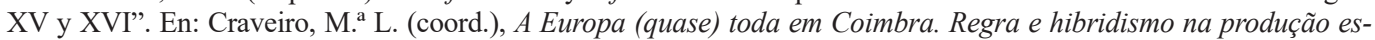
cultórica de João de Ruão, Coímbra.

Ibáñez, Javier / Alonso, Begoña (2016): "El cimborrio en la arquitecturra española de la Edad Media a la Edad Moderna. Diseño y construcción”. En: Artigrama, 31, pp. 115-202.

Loperráez Corvalán, Juan Bautista (1788): Descripción histórica de la diócesis de Osma, T. I, Madrid.

Marías, Fernando (1981): "Notas sobre Felipe Vigarny: Toledo y La Espeja”. En: BSAA, 47, pp. 425-429.

Marías, Fernando (1989): El largo siglo XVI, Madrid: Taurus.

Martínez y Sanz, Manuel (1866): Historia del templo catedral de Burgos, Burgos.

Moya, José Gabriel / Ramírez, José Manuel / Ruiz-Navarro, Julián / Ruiz, Hortensia (1975): Inventario de Logroño y su provincia, T. II, Madrid: Ministerio de Educación y Ciencia, Dirección General del Patrimonio Artístico y cultural.

Nicolau Castro, Juan (2003): "Los sepulcros del cardenal fray García de Loaysa y sus padres en el monasterio dominico de Talavera de la Reina". En: AEA, 76, 303, pp. 267-276.

Panosfky, Erwin (1970): El significado de las artes visuales, Buenos Aires.

Payo, René J. / Matesanz, José (2015): La Edad de Oro de la Caput Castellae, Burgos: Editorial Dos Soles.

Portal Monge, María R. Y. (1984): "Sepulcros del Convento del Corpus Christi". En: Salamanca. Revista Provincial de Estudios, 13, pp. 83-89.

Quarré, Pierre (1978): La sculpture en Bourgogne à la fin du Moyen Âge, París, Editions Vilo.

Redondo Cantera, María J. (2015): "El enfrentamiento entre Siloe y Bigarny en la comitencia y en los modelos artísticos". En: Leone, Pierluigi (dir.), Sculture e intagli ligeni tra Italia meridionale e Spagna, dal Quattro al Settecento, Italia: Artstudiopaparo, pp. 23-34.

Redondo Cantera, María J. (2017): "La obra burgalesa de Diego de Siloe". En: Gaeta, Letizia (dir.), Napoli e la Spagna nel cinquecento. Le opere, gil artisti, la storiografia, Salento: Mario Congedo Editore, pp. 45-91.

Sánchez Cantón, Francisco J.: "Los sepulcros de Espeja", AEAA, IX, 1933, pp. 117-125.

Vasallo Toranzo, Luis (2018a): "Imágenes de devoción para los poderosos. Diego de Siloe al servicio del obispo Juan Rodríguez de Fonseca y del contador Cristóbal Suárez". En: De Arte, 17, pp. 7-23.

Vasallo Toranzo, Luis (2018b): Los Fonseca. Linaje y patronato artístico, Valladolid, Universidad de Valladolid.

VV.AA. (Padres Cartujos de Miraflores) (1914): “El escultor Felipe de Vigarny o de Borgoña (datos inéditos)”. En: Boletín de la Sociedad Española de Excursiones, 22, pp. 262-268.

Fecha de recepción: 01-VI-2018

Fecha de aceptación: 14-I-2019 